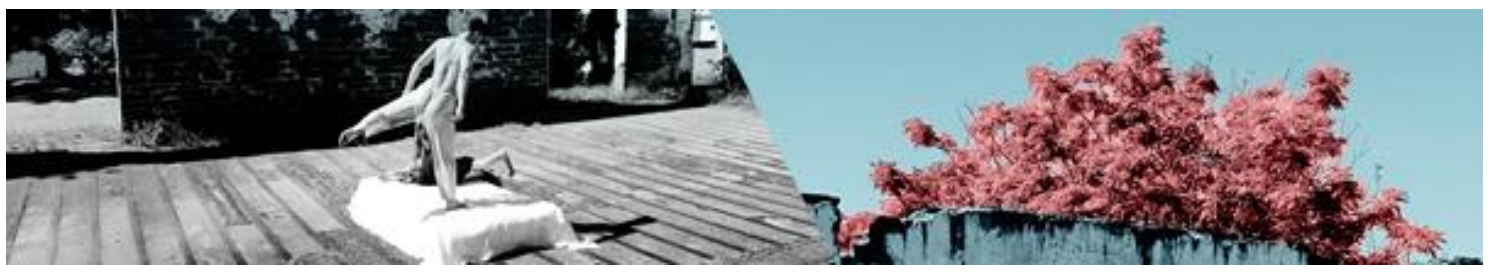

\title{
NA PELE: CONSTRUÇÕES ARTÍSTICAS ESTABELECIDAS ATRAVÉS DO BREGA
}

Genildo Gonçalves da Silva ${ }^{1}$ Francini Barros Pontos ${ }^{2}$

\begin{abstract}
Resumo: Este projeto visa abordar as construções artísticas estabelecidas através do brega, por meio de uma pesquisa na área de dança. Pretende-se socializar experiências que tratem desse estilo musical, estabelecendo relações pessoais/interpessoais, fazendo friç̧ão com a corporeidade enquanto dança, estabelecendo reflexões do conhecimento acerca dos saberes científicos e, além disso, buscar novas possibilidades de ensino em processos educacionais, levando em consideração o debate sobre o papel e a importância da inserção deste ritmo. Propõe-se, ainda, a levar os alunos ao exercício da reflexão acerca das dimensões culturais, políticas, sociais e históricas, bem como, problematizar o papel e a importância da inserção do brega enquanto dança na escola, fazendo uma ponte entre as origens culturais dos alunos e a erotização presente nas letras das músicas deste estilo musical.
\end{abstract}

Palavras-chave: Dança-educação, Erotização, Corpo, Brega.

\section{IN THE SKIN: ARTISTIC CONSTRUCTIONS ESTABLISHED THROUGH BREGA}

Abstract: This project aims to approach the artistic constructions established through the brega, through a research in the area of dance, it is intended to socialize experiences that deal with this musical style, establishing personal / interpersonal relationships, making friction with the corporeality while dancing, establishing reflections of the knowledge about scientific knowledge. In addition to seeking new educational possibilities in educational processes, taking into account the debate on the role and importance of the insertion of this rhythm. To bring students to reflect on the cultural, political, social and historical dimensions, as well as to problematize the role and importance of the insertion of the play as dance in the school, bridging the cultural origins of the students and the erotization present in the lyrics of the music of this musical style.

Keywords: Dance-Education, Erotization, Body, Brega.

\section{INTRODUÇÃO}

O tema da presente pesquisa: "Na Pele: Construções Artísticas Estabelecidas Através do Brega", foi fortemente influenciado pelas inquietações surgidas no compartilhamento da práxis vivenciada na disciplina de Estágio Curricular em Ensino da Dança IV. Verificou-se que a abordagem da dança como conteúdo da educação física muitas vezes não é realidade em sala de aula, e também o quanto o seu ensino tem deixado a desejar, uma vez que a dança é vista apenas como

\footnotetext{
${ }^{1}$ SILVA, G. G. - Acadêmico da Licenciatura em Dança da Universidade Federal de Pernambuco E-mail: genildo.ufpe13@hotmail.com;

2 PONTES, F. B. - Professora do Curso de Licenciatura em Dança da Universidade Federal Pernambuco; Email: francini.barros.p@gmail.com
}

SILVA, Genildo Gonçalves da; PONTOS, Francini Barros. Na pele: construções artísticas estabelecidas através da brega. Revista da FUNDARTE, Montenegro, p.456-482, ano 19, ㄲo 37, Janeiro/Março.

Disponível em: http://.seer.fundarte.rs.gov.br/index.php/RevistadaFundarte/index> 30 de março de 2019. 


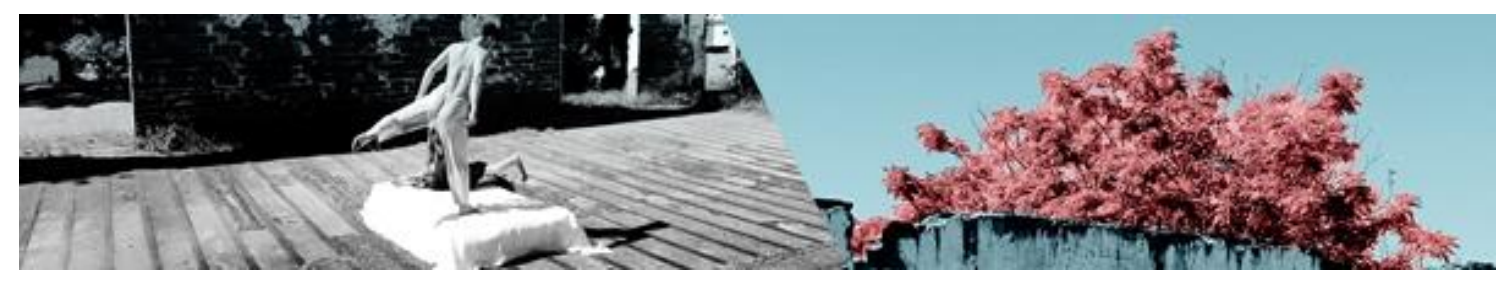

entretenimento em atividades extracurriculares. Acredita-se que existe a necessidade de estudar o papel da dança no contexto das periferias brasileiras. Em um país dançante como o Brasil, o assunto torna-se pertinente, pois existe uma diversidade de manifestações rítmicas e expressivas que causam repercussão dentro e fora do país, mas que não são aprendidas e discutidas na escola. Uma das causas dessa ausência é a limitação e o despreparo dos professores em relação à linguagem da dança.

A presente pesquisa assume, desta forma, um caráter pioneiro ao propor, através do estilo musical brega, uma investigação sobre novas possibilidades de ensino. A ideia é realizar um atravessamento entre a periferia e a escola, mostrando que é possível construir um diálogo artístico com o jovem no contexto educativo sem perder as dimensões metodológicas da dança, usando práticas em dança de forma a aproximar os alunos de suas respectivas realidades. Nossa preocupação é apresentar aos estudantes uma vivência que dialogue com seu cotidiano e o estilo musical brega, que é representativo da massa periférica do Recife, uma vez que as letras das músicas exprimem questões relacionadas ao contexto onde estão inseridos. Daí a escolha pela inclusão de aulas da dança brega no contexto escolar.

A pesquisa busca delinear caminhos para a estética da dança brega na escola, apresentando novas possibilidades de ensino, com o objetivo de analisar como as culturais locais vêm sendo contempladas na perspectiva dos professores e alunos da rede pública da cidade do Recife, tendo como enfoque o brega. $\mathrm{O}$ interesse por esse estilo deu-se principalmente por concentrar dentre seus praticantes uma grande diversidade de gênero e os tabus a eles relacionados, bem como, pela escassa produção científica sobre o assunto. O intuito é compreender como os processos de ensino da dança podem contribuir com suas vivências corporais, visto que estão impregnadas nos corpos dos praticantes, levando em consideração as suas ações cotidianas.

Para tanto, surge a questão: a sociedade está apta a reconhecer o brega enquanto conteúdo a ser mediado na escola a partir de uma metodologia própria de ensino da dança? Buscando responder à questão apresentada, partimos do princípio

SILVA, Genildo Gonçalves da; PONTOS, Francini Barros. Na pele: construções artísticas estabelecidas através da brega. Revista da FUNDARTE, Montenegro, p.456-482, ano 19, ㄲo 37, Janeiro/Março.

Disponível em: http://.seer.fundarte.rs.gov.br/index.php/RevistadaFundarte/index> 30 de março de 2019. 


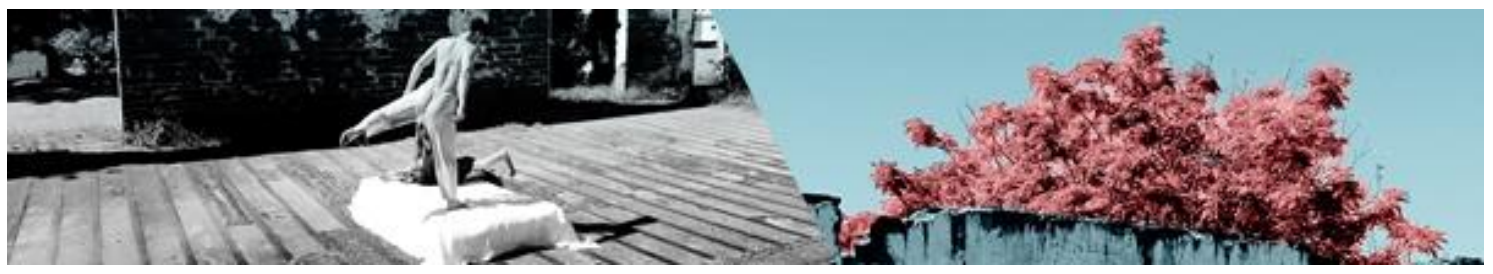

de que a dança deve ser trabalhada no contexto escolar, uma vez que corrobora em diversos aspectos com a formação do aluno: a expressão e a consciência corporal, a espontaneidade, a relação interpessoal, a criatividade, a cidadania, a responsabilidade, o ritmo, a flexibilidade e a socialização. A dança torna-se, dessa forma, uma ferramenta preciosa para o indivíduo lidar com suas necessidades, desejos, expectativas e também como instrumento para seu desenvolvimento individual e social.

\section{REFERÊNCIA TEÓRICO}

\section{O BREGA E SUA HISTORIOGRAFIA}

Para a compreensão desta pesquisa, iremos abordar um pouco sobre a historicidade do brega e suas dimensões de territorialidade. O surgimento desse estilo gera muitas discussões: há quem afirme que o nome vem dos bordéis nordestinos em que esse tipo de música era usado para embalar os romances de aluguel.

Segundo Paulo César de Araújo (2002, p. 18-20), o termo brega passou a ser empregado no início da década de 80 para designar uma nova vertente dentro de um grupo de cantores anteriormente conhecidos como cafonas. Logo, essa nomenclatura era usada para nomear as produções musicais consideradas desagradáveis por uma considerável parcela da sociedade, uma vez que as pessoas que têm acesso a este gênero musical são das camadas econômicas mais baixas. Eduardo Esteves (2017, p.1) aponta:

No final da década de 1960 e início de 1970, o ritmo surgiu no Brasil, mas ainda era apresentado como "música romântica popular". Cantores como Odair José, Fernando Mendes, Agnaldo Rayol e Leonardo Sullivan não diziam cantar "brega", muitas vezes por achar que a expressão diminuía o trabalho deles e não os representava. Nesse primeiro momento do brega, as letras eram mais românticas e o ritmo era influenciado por cantores como Elvis Presley e Frank Sinatra. (ESTEVES, 2017, p.1).

Em Pernambuco, os cantores eram denominados cafonas ${ }^{3}$ de forma depreciativa,

\footnotetext{
${ }^{3}$ Segundo Paulo César Araújo, cafona é uma palavra de origem italiana, Cafóne (sujeito humilde, vilão, tolo) e divulgada no Brasil pelo jornalista e compositor Carlos Imperial, definida na Enciclopédia da Música Brasileira como "Coisa barata, descuidada e malfeita" e a "música mais banal, óbvio,

SILVA, Genildo Gonçalves da; PONTOS, Francini Barros. Na pele: construções artísticas estabelecidas através da brega. Revista da FUNDARTE, Montenegro, p.456-482, ano 19, no 37, Janeiro/Março.

Disponível em: http://.seer.fundarte.rs.gov.br/index.php/RevistadaFundarte/index> 30 de março de 2019.
} 


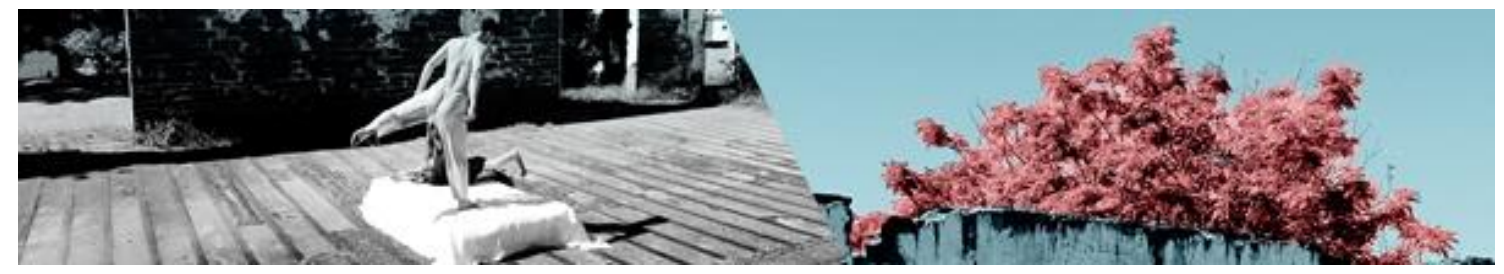

reduzindo seu valor artístico por seguirem um gênero musical que não se enquadrava aos padrões da época. Os legítimos representantes do brega, os cantores Reginaldo Rossi, Adilson Ramos, Nelson Ned, Nelson Gonçalves, Sidney Magal, Vicente Celestino, Falcão e Wando não só continuavam populares, quanto progressivamente crescia sua inserção no circuito musical pela crescente quantidade de shows realizados. Logo, o movimento do brega no Recife se fortalecia com o surgimento de novas bandas, e se empoderava enquanto estilo musical das periferias, que pouco a pouco tomou conta da cidade.

Esses termos, que denotam claramente um juízo negativo de valor, foram atribuídos por uma crítica. A música que considera essa produção musical "tosca, vulgar, ingênua e atrasada", e que segundo Araújo se ressentia de fato de que aquilo que se convencionou chamar "Música Popular Brasileira", conceito que designava quase sempre músicos engajados contra o regime ditatorial da época, não conseguia ser tão popular quanto cafona como Amado Batista, Odair José, Nelson Ned, Agnaldo Timóteo, Waldick Soriano ou Reginaldo Rossi, entre outros. (FONTANELLA, 2005, p. 21).

No Recife, o brega, em toda sua historicidade, vem quebrando paradigmas e buscando sua ascensão em meio às culturas esteticamente eleitas pela sociedade como detentoras de padrões considerados relevantes entre as artes, apesar da conotação pejorativa a ele atribuída, já que contém, nas letras das músicas, o cotidiano da população.

O brega marca sua presença, na atualidade, em festas de grande porte frequentadas pela burguesia, bem como em escolas, periferias e nas ruas do Recife. Apesar de esse gênero musical permanecer escanteado, há os que o defendam e o a propaguem. Embora seja tênue a linha que divide os gêneros musicais e suas dimensões estéticas, sempre haverá uma hierarquia a denotar qual gênero musical é apropriado, servindo como referência a estética de mercado. Esses tipos de hierarquias geram lideranças que ditam o que vamos ouvir, vestir e até mesmo o que vamos fazer de nossa vida profissional.

Assim, Reginaldo Rossi trazia em suas produções musicais letras românticas que exprimiam a sua vida. Como por exemplo, a música "Meus avós”, em que retrata como foi

direta, sentimental e rotineira possível, que não foge ao uso sem criatividade de clichês musicais ou literários". (ARAÚJO, 2002: 20).

SILVA, Genildo Gonçalves da; PONTOS, Francini Barros. Na pele: construções artísticas estabelecidas através da brega. Revista da FUNDARTE, Montenegro, p.456-482, ano 19, ํㅡ 37, Janeiro/Março.

Disponível em: http://.seer.fundarte.rs.gov.br/index.php/RevistadaFundarte/index> 30 de março de 2019. 


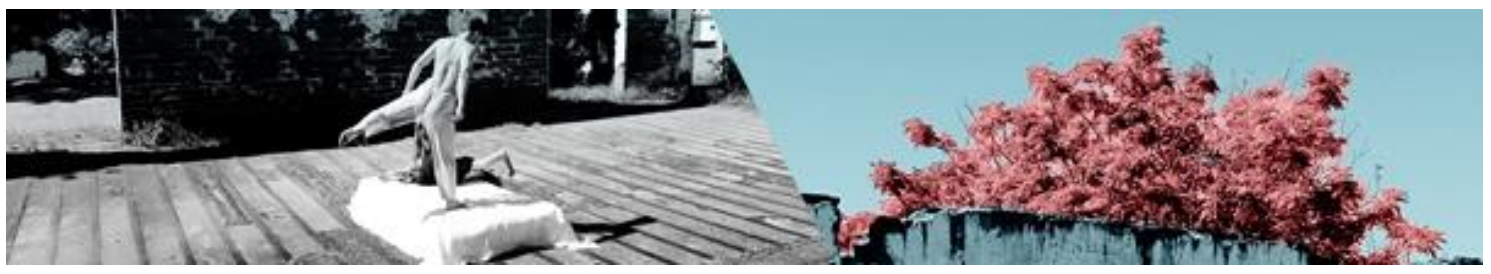

criado: "minha avó, Antônia Rossi, ela me criou e foi um pai, uma mãe, um avô e uma avó pra mim. Dona Antônia era uma italiana linda, de olhos verdes, que se casou com um negrão. Por isso, tenho o cabelo assim”. Era com essas letras que o músico cativava seus fãs. (FONTANELLA, 2005, p. 74) afirma:

\begin{abstract}
A ideologia estética de corpo que foi criada pelo movimento do brega Pernambucano sofreu diversas mudanças que foram significativas ao decorrer de sua trajetória até os dias de hoje, mudanças essas que são notáveis por seus consumidores durante os shows. Logo, as mulheres roubam a cena mostrando sexualidade em seus movimentos sutis. A ordem é ser magro, jovem, ter um corpo moldado por uma disciplina de exercícios e dietas, cujas formas perfeitas serão ressaltadas por roupas provocantes (FONTANELLA, 2005, p. 74).
\end{abstract}

As referências culturais do brega nos bairros do Recife são bastante presentes, e a relação sensualista revelada nas letras das músicas reverbera nas vestimentas das mulheres e em sua postura no que se refere à submissão, afirmando os homens como mais rudes em sua figura simbólica nas letras das músicas, que sempre apresentam sua figura como dominante. Embora exista um grande número de artistas na atualidade que retratam em suas músicas letras românticas, ainda podemos notar a hierarquia entre os gêneros, como por exemplo, na música da Banda Musa do Calypso "chega de papo, é tanta conversa fiada é tanta lusa, pensando que sou otária me faço de boba, só pra ver suas mancadas, estás me traindo bem ao lado da minha casa". No trecho da música acima, podemos perceber o quanto a mulher é tida como objeto, mesmo quando a letra tem um teor romântico. Podemos citar as bandas da atualidade que abordam em suas músicas um repertório romântico, são: Musa do Calypso, Banda Torpedo, Michelle Melo e Tayara Andreza, entre outras. É interessante perceber também o sucesso repentino de artistas, que, em pouco tempo estão fazendo o maior sucesso, são eles: André Viana, Michelle Melo, Tayara Andreza, Banda Torpedo, Mc Elvis, Mc Japa, Mc Japão, Mc Troia, Mc Metal e Musa do Calypso. São essas as potências artísticas do brega no Recife, que vem ocupando os grandes palcos nas noites. Assim, as culturas periféricas vêm lutando por legitimidade.

Pensar no brega enquanto movimento artístico e estético traz uma grande

SILVA, Genildo Gonçalves da; PONTOS, Francini Barros. Na pele: construções artísticas estabelecidas através da brega. Revista da FUNDARTE, Montenegro, p.456-482, ano 19, ㄲo 37, Janeiro/Março.

Disponível em: http://.seer.fundarte.rs.gov.br/index.php/RevistadaFundarte/index> 30 de março de 2019. 


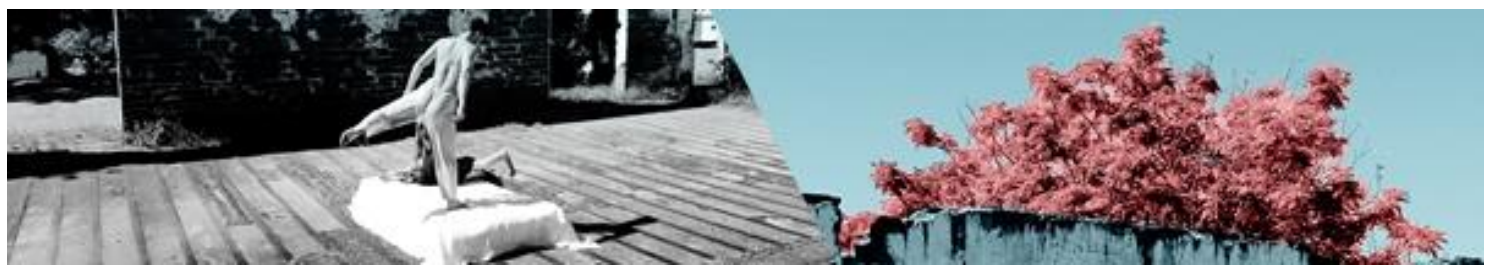

responsabilidade política, social e econômica. $O$ centro, a periferia 4 e suas dimensões de territorialidade estão paradoxalmente interligadas e dissociadas através da arte. As fricções entre o centro e a periferia possibilitam problematizar os fazeres artísticos e pedagógicos das experiências estéticas.

A identidade artística de regiões que supostamente resistem à contaminação com tudo o que Ihes seja distinto; por outro, recusa o entendimento de que a arte feita em um lugar seja apenas a expressão especializada de uma língua que se autografa a condição de universal e que seria assim por todos igualmente entendida (DOS ANJOS, 2003 p120).

No Brasil, os artistas buscam compreender a arte e a cultura de outros países como meio de se reinventar em futuras construções artísticas, o que produz, genericamente, trabalhos gerenciados por fatores homogêneos. Ana Mae ressalta: "Não podemos entender a cultura de um país sem conhecer sua arte" (BARBOSA, 2002, p. 17). Nesse contexto, as relações estabelecidas entre as culturas e as artes de outros países, que são tidas como atuais, tornam-se motes de criação para os artistas brasileiros. Nesse processo de hibridização, muitas vezes, a cultura local é negligenciada pelos agentes da cultura brasileira, ocasionando uma perda de identidade e a desterritorialização de nossa arte; deixamos de legitimar nossa cultura dominante construindo fazeres genéricos.

Tais operações de desterritorialização possuem, além disso, um indissociável caráter político, posto que se o fruto desses embates é a recriação do sistema das formas que governam aquilo que se pode ser visto e aquilo que pode ser dito, isso alarga e recompõem o mundo da percepção e o mundo do sensível, reconfigurando os temas e as atitudes passíveis de serem expressas e ouvidas (DOS ANJOS, 2003, p. 118).

Nesse sentindo, a perda de identidade e de desterritorialização, que gera a fricção entre as culturas, forma artistas híbridos que dialogam com outros contextos políticos,

\footnotetext{
${ }^{4}$ No plano da evolução da sociedade, que corresponde ao modelo de Niklas Luhmann (LUHMANN \& DE GIORGI, 1993), Neves (2006) enfatiza o caráter intermediário dessa forma de diferenciação, localizando-a entre uma forma segmentar de sociedade e outra estratificada; à primeira correspondendo estruturas mais simples caracterizadas pela indiferenciação, e à segunda, correspondendo um tipo de desigualdade de nível entre "nobreza" e "povo". Ainda que Luhmann tenha abandonado essa forma de diferenciação para a sociedade moderna, ela ainda se apresenta pertinente quando se leva em conta o caráter hierárquico da produção de paradigmas científicos e tecnológicos.
}

SILVA, Genildo Gonçalves da; PONTOS, Francini Barros. Na pele: construções artísticas estabelecidas através da brega. Revista da FUNDARTE, Montenegro, p.456-482, ano 19, no 37, Janeiro/Março.

Disponível em: http://.seer.fundarte.rs.gov.br/index.php/RevistadaFundarte/index> 30 de março de 2019. 


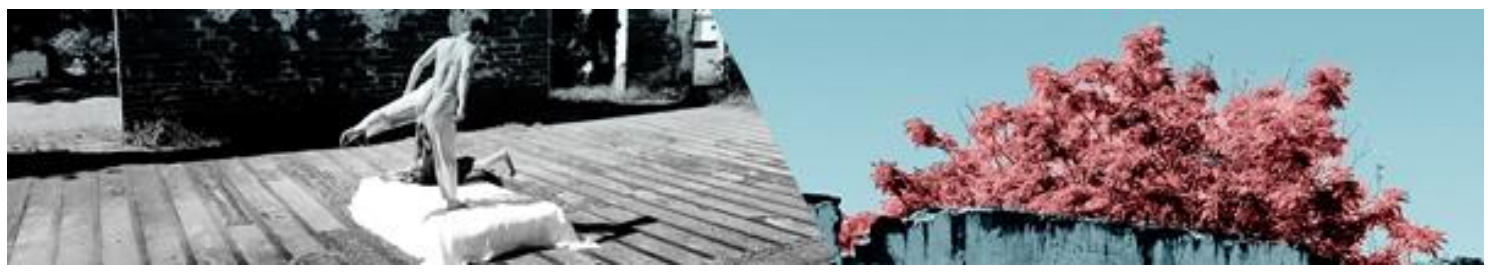

culturais e sociais. Essa desconstrução que vem se alastrando em meio aos artistas contemporâneos vem deixando as culturas populares desfavorecidas. A cultura popular acaba assim por ser incorporada pelos meios de comunicação, recortada e inserida nos novos meios tecnológicos, dicotomizada, hierarquizada e polarizada, sendo utilizada como uma das formas de reforçar a hegemonia dominante, deixando seu contexto e suas bases para se transformar, antes, numa alegoria de consumo.

\begin{abstract}
A concepção de uma arte contemporânea menor está mais de acordo, por isso, com conceitos adotados ou desenvolvidos no âmbito disciplinar dos estudos culturais, tais como a mestiçagem, o sincretismo, a crioulização e o hibridismo, posto que também estes permitem compreender a alteridade da invenção artística de que é subordinado através do atrito simbólico e político com o outro que o subordina .(DOS ANJOS, 2003, p. 120).
\end{abstract}

Cabe perguntar: de que modo os componentes básicos formadores da cultura popular são apropriados pelos sistemas? Ao estudar as culturas populares vale conscientizar-se das potencialidades implícitas no seu modo de construção de conteúdo. O brega, a capoeira, o funk e o hip hop são manifestações culturais que surgiram entre os povos como meio de enfretamento da sociedade idealista. Dos Anjos (2003, p.120) cita: "O termo gambiarra, evocado com frequência crescente por artistas e críticos para caracterizar a arte brasileira, mas carente de conceituação suficientemente precisa para que tenha efetivado, na reflexão sobre o assunto em foco, o potencial cognitivo que possui." A partir do conceito de gambiarra cunhado pelo autor, pode-se perceber que esse viés urbano e popular da arte brasileira ainda é tido como menor.

\begin{abstract}
Importa aclarar, desde logo, que a gambiarra designa tanto o ato de construir algo em função da escassez de recursos para resolver problemas variados quanto os próprios aparatos que são assim criados. A gambiarra é, portanto, uma operação e o seu resultado, uma tecnologia e seu produto: a emenda dos fios e os fios emendados, a captação fraudulenta de energia elétrica e sua concreção em cabos, tomadas e fitas articuladas. (DOS ANJOS, 2003, p. 121-122).
\end{abstract}

A gambiarra é utilizada como metáfora para a arte, e torna-se um dispositivo de ruptura no sistema opressor da mesma, que busca se ressignificar através de

SILVA, Genildo Gonçalves da; PONTOS, Francini Barros. Na pele: construções artísticas estabelecidas através da brega. Revista da FUNDARTE, Montenegro, p.456-482, ano 19, no 37, Janeiro/Março.

Disponível em: http://.seer.fundarte.rs.gov.br/index.php/RevistadaFundarte/index> 30 de março de 2019. 


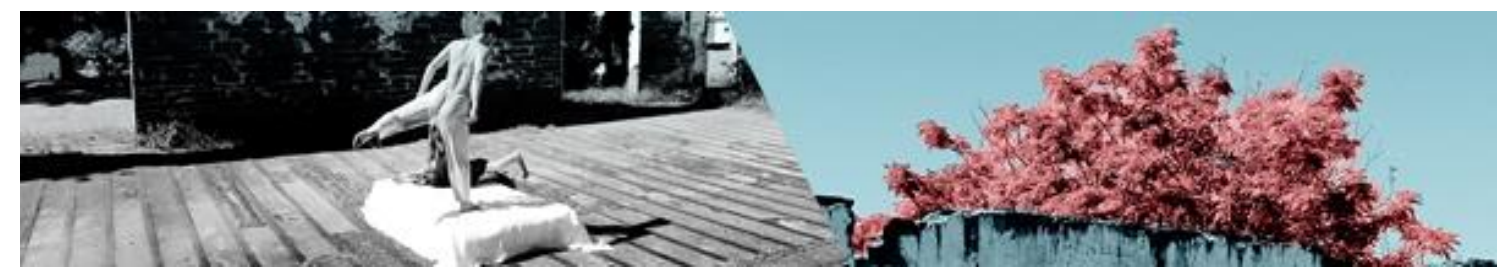

estratégias que visam manter a diversidade entre os indivíduos. "A gambiarra, portanto, é um termo que pode ser utilizado para caracterizar produções culturais e artísticas híbridas que são geradas, desde um determinado lugar, como modos de posicionar-se frente ao processo de homogeneização simbólica em curso". (Dos Anjos, 2003, p. 124).

Os movimentos periféricos, sobretudo o brega, vêm sendo objeto de estudo de inúmeras pesquisas acadêmicas, propiciando sua saída da periferia e a conquista de espaços na academia. A força do brega é tão grande no Estado de Pernambuco, que em abril de 2017 a Assembleia Legislativa de Pernambuco (ALEPE), aprovou o Projeto de Lei nº1176/2017, responsável por elevar o ritmo à categoria de expressão cultural Pernambucana. Embora o brega tenha atingido esse reconhecimento, sua trajetória está impregnada de marginalização e exclusão por parte do mercado e da indústria fonográfica, por ser considerado um gênero musical de "mau gosto". Atualmente, o brega é reconhecido a nível nacional.

Logo, para se analisar o fenômeno do brega, é necessário partir de uma abordagem que considere o lugar de fala de um estudo acadêmico, produzido por agentes que participam dos códigos do discurso hegemônico e permeados por esses hábitos, evitando assumir preconceitos apriorísticos. Essa abordagem foi encontrada no grupo de estudo conhecido como subaltern studies, uma corrente de pensadores, oriundos principalmente de países periféricos, que se dedicou a entender atitudes estratégicas para contornar a condição de subalternidade impostas no contexto cultural pósmoderno, tentando evitar uma visão preservacionista das culturas locais ou um darwinismo cultural. (FONTANELLA, 2005, p. 16).

Entretanto, atrelado aos povos ditos periféricos, existe um movimento que busca o fortalecimento das culturas que caracterizam a luta desses povos no dia a dia, bem como, deve-se perceber a conjuntura política e social preconceituosa e machista que ainda tem dominância nas comunidades. Oswald de Andrade (1928, p.37) afirma que: "a periferia nos une pelo amor, pela dor e pela a cor. Dos becos e vielas há de vir à voz que grita contra o silêncio que nos pune. Eis que surte das ladeiras um povo lindo e inteligente galopando contra o passado. A favor de um futuro limpo, para todos os brasileiros".

\section{A INSERÇÃO DO BREGA NA ESCOLA E SUAS CONTRIBUIÇÕES}

SILVA, Genildo Gonçalves da; PONTOS, Francini Barros. Na pele: construções artísticas estabelecidas através da brega. Revista da FUNDARTE, Montenegro, p.456-482, ano 19, no 37, Janeiro/Março.

Disponível em: http://.seer.fundarte.rs.gov.br/index.php/RevistadaFundarte/index> 30 de março de 2019. 


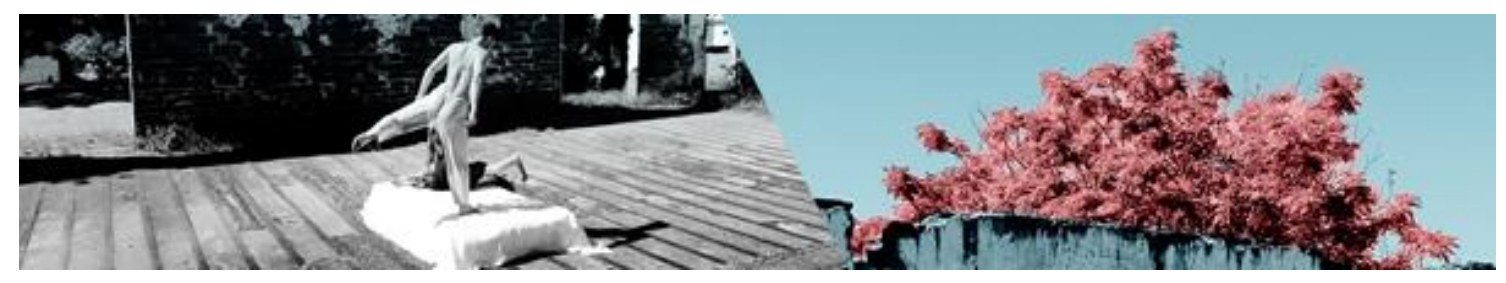

Este estudo apresenta os resultados obtidos sobre o trabalho desenvolvido a partir da proposta da inserção do brega enquanto dança no espaço escolar. Os estudantes alvos desse estudo foram os alunos da rede pública estadual de ensino, especificamente do nível médio ( $1^{\circ}$ ao $2^{ }$ano) da escola EREM Diário de Pernambuco. Esta instituição está situada na Rua Costa Sepúlveda, bairro do Engenho do Meio, Recife - PE, e atende, em sua maioria, adolescentes de vários bairros. Havia aproximadamente 300 alunos no período da pesquisa.

Inicialmente, a pesquisa seria realizada em duas escolas da rede pública, porém, tornou-se inviável essa amostragem por se tratar de um estudo amplo e continuado com a realização de atividades que envolveriam um número elevado de dados, o que dificultaria a conclusão da pesquisa. Portanto, foi selecionada uma escola conforme a disponibilidade da instituição.

De início, propomos aos alunos que construíssemos um conhecimento sobre cultura e arte. Para Marcelo Gruman, o termo "cultura" refere-se ao significado que um grupo social dá à sua experiência, incluindo ideias, crenças, costumes, artes, linguagem, moral, direito, culinária etc. (GRUMAN, 2012, p.200). A partir dos relatos, direcionei os alunos para o questionamento e a análise sobre seu entendimento acerca do conceito de cultura, acima citado.

Com base nos conhecimentos prévios expostos, colocamos uma música de estilo brega e foi solicitado que os participantes fechassem os olhos e ouvissem para depois compartilharem o que sentiam ao ouvir tal ritmo. Ficamos surpresos com as respostas. Foi nítido o vínculo detectado pelas falas e argumentos usados pelos indivíduos, no sentido do reconhecimento da pertinência do conteúdo exposto no espaço escolar, uma vez que o brega está vivo nos corredores da escola, nos intervalos de uma aula para outra. Com o exposto, foi possível questionar sobre o real motivo da inserção do brega na escola enquanto dança, verificando como o gênero engloba as discussões sobre os preconceitos presentes na atualidade.

A falta de identificação histórica é o principal motivo para um distanciamento das culturas periféricas nos processos de interculturalidade no país. Assim, identificamos que é nesses lugares, tidos como periféricos, que se evidenciam as

SILVA, Genildo Gonçalves da; PONTOS, Francini Barros. Na pele: construções artísticas estabelecidas através da brega. Revista da FUNDARTE, Montenegro, p.456-482, ano 19, no 37, Janeiro/Março.

Disponível em: http://.seer.fundarte.rs.gov.br/index.php/RevistadaFundarte/index> 30 de março de 2019. 


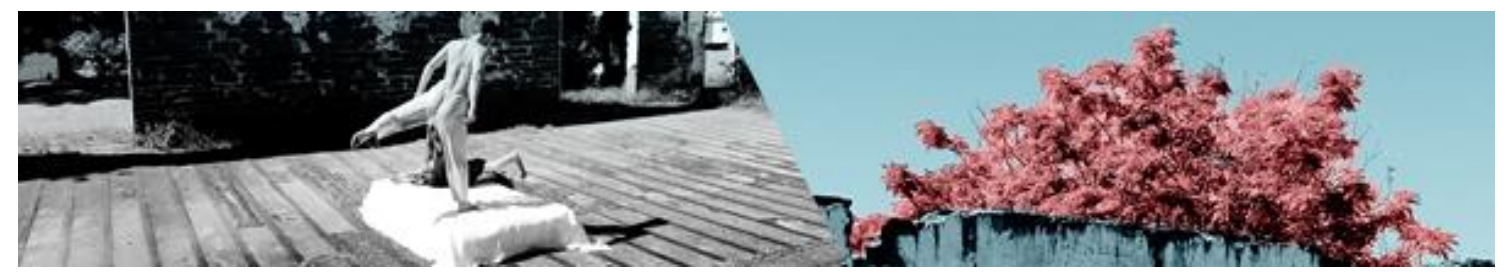

indagações e a necessidade de esclarecimentos sobre as problemáticas e os preconceitos detectados, o que justifica sua presença em sala de aula. Para a construção de uma futura geração sem preconceito, será necessário contar com as contribuições e desconstruções do presente, então nos perguntamos: o que estamos construindo para o futuro? Alunos conscientes que sabem viver em sociedade respeitando as diferenças e construindo entre elas equidade?

Assim, diante desse contexto, ter o entendimento do que vem a ser arte é de suma importância. Grumas acrescenta: "a arte é um meio de representação da realidade, uma construção social, percepção de nós mesmos no mundo possibilitando-nos assumir modelos de identidade e comportamento". (GRUMAN, 2012, p.202). Em Pernambuco, a arte possuiu um caráter de "ponte" na escola, entre a educação e a cultura popular. Em relação à dança e sua presença na escola, tal aproximação configurou-se como uma prática, um estilo, a construção de um repertório corporal, gerando rupturas com as camadas periféricas que dialogam diretamente com a escola. Este pensamento está fundamentado e norteado pela metodologia triangular de Ana Mae Barbosa, que consiste no reconhecimento de três abordagens para se construir conhecimento em Artes. A professora e pesquisadora é referência nacional sobre o ensino de artes no Brasil e sistematizou sua "abordagem triangular" no final da década dos anos de 1980. Ela propõe que o conhecimento em artes deve ser articulado incluindo três ações: apreciar, fazer e contextualizar. Essa proposta possibilita um ensino significativo em Artes, no sentido de promover a capacidade criativa e crítica do aluno no fazer artístico e na sua reflexão sobre o processo de produção das Artes.

A abordagem triangular possibilita diferentes caminhos no âmbito que a envolve: o do fazer, o do ler e o do contextualizar. A imagem do triângulo permite ao professor escolher em qual das pontas iniciará seu trabalho. Por isso, é uma abordagem dialógica. Sua potência está na relação entre a tríade que permite a reordenação da prática docente. Assim, não deve ser tomada como um passo a passo. Isso seria perder suas significações em um vazio. Segundo Barbosa, "[...]

SILVA, Genildo Gonçalves da; PONTOS, Francini Barros. Na pele: construções artísticas estabelecidas através da brega. Revista da FUNDARTE, Montenegro, p.456-482, ano 19, ㄲo 37, Janeiro/Março.

Disponível em: http://.seer.fundarte.rs.gov.br/index.php/RevistadaFundarte/index> 30 de março de 2019. 


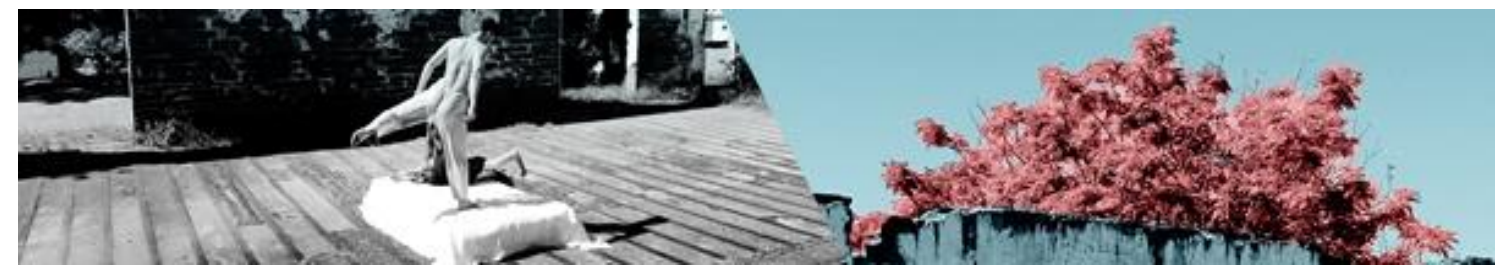

trata-se de uma abordagem flexível. Exige mudanças frente ao contexto e enfatiza o contexto". (Barbosa, 2010, p.10)

Em toda a nossa vida, vivemos em processos de aprendizagem, nos quais nos colocamos em campo para experimentações que vão gerar vivências ímpares. Estar no meio professor/aluno nos permite criar diálogos entre corpos com experiências singulares, mas com um só propósito que é o do conhecimento. Logo, irão surgir desafios que vão servir como instrumento de aprendizado. Segue um resumo da experiência de ensino da dança do brega na escola, segundo parâmetros da abordagem triangular:

\section{CONTEXTUALIZAÇÃO HISTÓRICA}

Foi utilizado como ferramenta metodológica o mapa desmontável criativo, no qual os alunos eram divididos em grupos. Cada equipe recebia uma ficha que elucidava a história do brega. Em seguida, eram designados a construir coletivamente o mapa, tendo como base o que assimilaram do que foi lido. No decorrer da aula eram escolhidos alunos, de forma aleatória, para expor para a turma o que entenderam da ficha e por que escolheram expor. No final da apresentação dos grupos, foi explicado de forma cronológica o processo do brega, com o intuito de gerar um compartilhamento através da oralidade, que é uma via comum de registro de muitos campos de conhecimento da vida na periferia. Buscava sempre iniciar cada eixo temático a partir da sua historicidade, pela importância do reconhecimento da constituição desse ser histórico. Tudo feito para que os alunos pudessem se situar na cultura em que estão incluídos.

\section{FAZER ARTíSTICO}

Iniciamos o fazer artístico pelo corpo, através da sistematização dos fatores de movimento de Rudolf Laban, repassando movimentações e marcações dos pés, mãos e restante do corpo. Através do ritmo marcado pelas músicas do brega, buscamos implantar/enraizar nos alunos, pelo corpo, a sua identidade, por meio de uma improvisação guiada que se desdobrava a partir dos modos de aplicação de

SILVA, Genildo Gonçalves da; PONTOS, Francini Barros. Na pele: construções artísticas estabelecidas através da brega. Revista da FUNDARTE, Montenegro, p.456-482, ano 19, no 37, Janeiro/Março.

Disponível em: http://.seer.fundarte.rs.gov.br/index.php/RevistadaFundarte/index> 30 de março de 2019. 


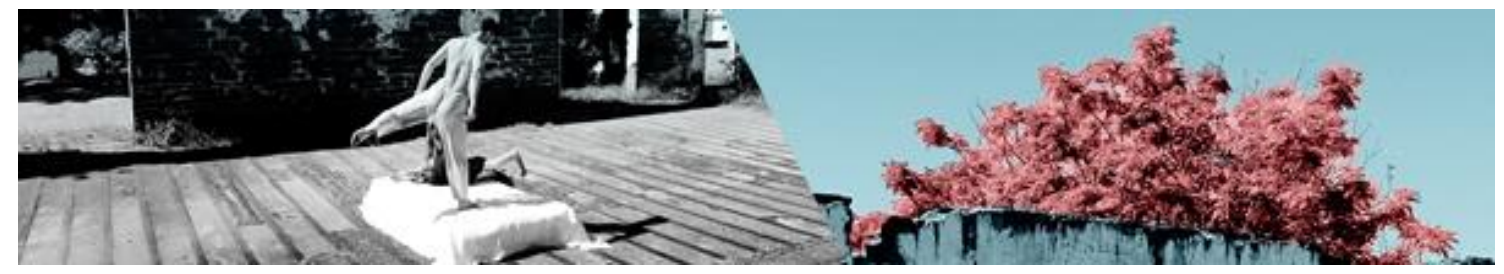

referência de Rudolf Laban, que são: I Consciência do corpo, II consciência do peso e tempo, III consciência do espaço, IV consciência da fluência do peso corporal no espaço e no tempo, V adaptação a parceiros, VI Instrumental do corpo, VIII consciência das oito ações de esforço básico.

\section{APRECIAÇÃO ARTÍSTICA}

Por incrível que pareça, os alunos não se recordavam se haviam assistido a espetáculos e performance de danças. As únicas vivências que eles tinham no corpo, era do brega, forró e swingueira - ritmos bastente conhecidos no Nordeste brasileiro. Logo, foi proporcionada uma fricção entre essas danças elegidas por eles, e, em seguida, foi solicitado que evidenciassem tudo que foi incorporado através das pesquisas e vivências, de forma a colar em nossa prática o que havia sido por eles contemplado. Essas vivências, em particular, foram bastante construtivas e modificadoras, trazendo um esclarecimento sobre os rumos da carreira do pesquisador principal deste trabalho como futuro docente, resultando no levantamento de problemáticas e indagações sobre as metodologias e avaliações usadas nesse processo. Não foi possível aproveitar o quanto realmente queria, ou fazer o que realmente havia sido planejado pelas mudanças e nuances que ocorriam no calendário escolar.

Por mais que os alunos possuíssem uma aproximação com o brega, era perceptível como necessitavam de uma educação corporal pela educação somática, em razão de que esta propicia a consciência do movimento, contemplando a saúde, a arte e a dança.

Nessa pesquisa, as vivências foram transformadoras e se desdobraram na perspectiva de uma construção metodológica através do brega, visando adentrar nas camadas periféricas. A dança do brega está vivendo um novo momento dentro da escola, sobretudo na EREM Diário de Pernambuco, onde foram propostas as práticas em dança relacionadas a este estilo musical, apesar do estranhamento de

SILVA, Genildo Gonçalves da; PONTOS, Francini Barros. Na pele: construções artísticas estabelecidas através da brega. Revista da FUNDARTE, Montenegro, p.456-482, ano 19, no 37, Janeiro/Março.

Disponível em: http://.seer.fundarte.rs.gov.br/index.php/RevistadaFundarte/index> 30 de março de 2019. 


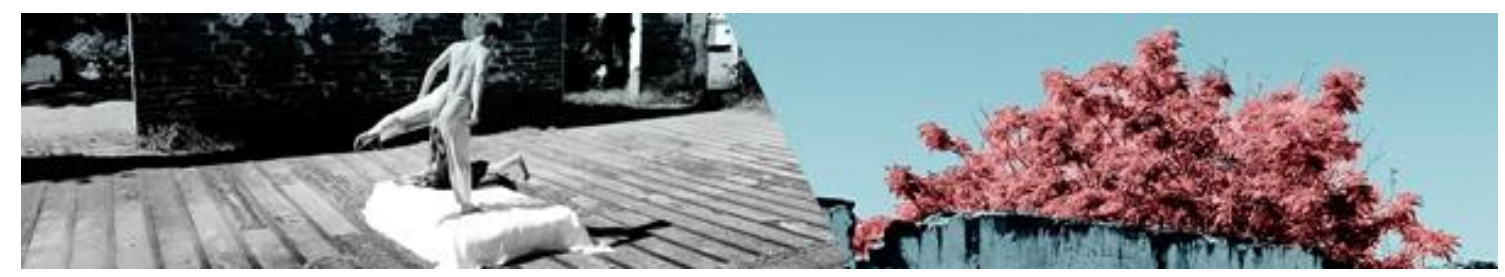

alguns alunos, principalmente por estarem ligados a religiões que não permitem sua inserção na dança do brega, tida como mundana.

Através da observação na unidade de ensino, pudemos constatar que a experiência na sala de aula é de grande importância para a formação do futuro docente, possibilitando novas percepções sobre o ensino. A prática do estágio na mesma escola em questão possibilitou novas experiências e conhecimentos para a futura profissão; através das observações, adquirimos possibilidades para trabalhar com diferentes metodologias de ensino. A dança sempre esteve presente no espaço escolar observado, o Diário de Pernambuco, visto que os profissionais da escola ressaltam que a dança é importante na vida cotidiana dos alunos, porque desenvolve habilidades como: controle sobre o corpo e o movimento, equilíbrio, coordenação, alegria, desenvolvimento cognitivo e afetivo; também porque traz leveza ao ambiente escolar, tornando-o aconchegante e acolhedor, estímulo imprescindível para o desenvolvimento de novas experiências e a reinvenção de possibilidades de aprendizado.

As contribuições da inserção da dança do brega na escola partem das relações culturais, sociais e políticas que permitem uma percepção crítica, tanto da dança quanto de suas relações consigo e com mundo, corroborando a reinvenção de uma realidade que coexiste entre a periferia e a escola, sobretudo, traçando novos rumos para se pensar a dança como instrumento pedagógico. "Entre outros benefícios, a dança proporciona: melhoria nas relações interpessoais, ajuda na saúde mental, redução de ansiedade, stress e sedentarismo." (MARQUES, 1997).

\section{REFLEXÕES SOBRE O ESPAÇO DA DANÇA NA DISCIPLINA DE ARTE, NA ESCOLA}

A disciplina de artes faz parte do currículo da escola Diário de Pernambuco, mas as aulas são direcionadas apenas para $01^{\circ}$ e $02^{\circ}$ ano do ensino médio, ministradas duas vezes por semana, com a carga horária de 50 minutos. A disciplina contempla quatro turmas destas séries. Tivemos oportunidade de conhecer e vivenciar os processos práticos e teóricos em todas as turmas, o que significa que

SILVA, Genildo Gonçalves da; PONTOS, Francini Barros. Na pele: construções artísticas estabelecidas através da brega. Revista da FUNDARTE, Montenegro, p.456-482, ano 19, ㄲo 37, Janeiro/Março.

Disponível em: http://.seer.fundarte.rs.gov.br/index.php/RevistadaFundarte/index> 30 de março de 2019. 


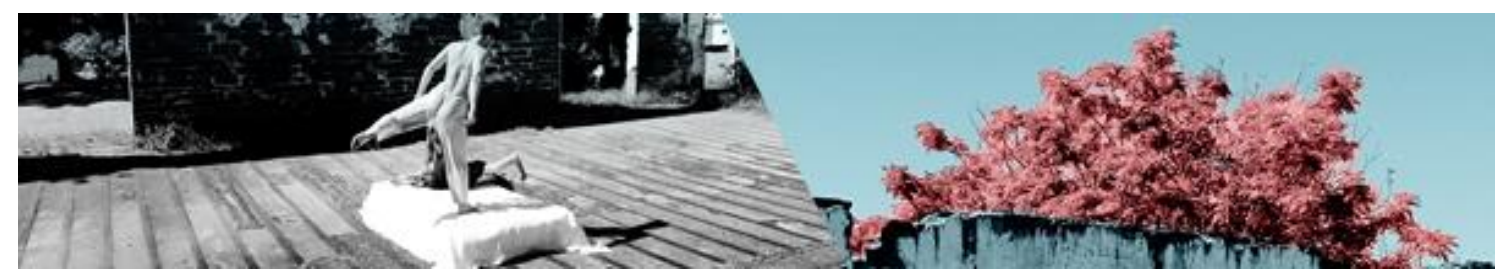

os dados obtidos em uma única turma se configuram como uma amostragem que não desqualifica ou diminui o objetivo da pesquisa, visto que acumulamos experiência em todas as turmas.

As observações a partir das vivências em sala de aula permitiram verificar como é a "ocupação" da disciplina de artes no espaço escolar, ressaltando que não se pode generalizar através das conclusões feitas, pois este é um estudo que busca compreender, especificamente, como se dão as práticas de dança em diálogo com o brega, na escola.

A professora que ministra as aulas de artes não possui formação na área, ela é graduada em Letras - Português. Para que o ensino das artes aconteça, é necessária a qualificação do professor nas linguagens específicas e a definição de metodologias apropriadas para o ensino de cada linguagem: artes visuais, dança, música e teatro. A necessária especificidade da formação dos professores está garantida pela Lei № 13.278 de 02 de maio de 2016, que não só determina a obrigatoriedade do ensino das quatro linguagens no componente curricular de Artes, mas o faz sendo mediado por profissionais de formação específica. A Lei ainda determina: "art. $2^{\circ} \mathrm{O}$ prazo para que os sistemas de ensino implantem as mudanças decorrentes desta Lei, incluída a necessária e adequada formação dos respectivos professores em número suficiente para atuar na educação básica, é de cinco anos" 5 .

O professor que assume as aulas de artes sem formação específica, especialmente no contexto do ensino fundamental II e do ensino médio, em que o profissional já não é polivalente, deve buscar, através de intensa pesquisa, acessar os conhecimentos básicos da linguagem em questão, procurando aprender, minimamente, sobre este campo de atuação pedagógica. O conhecimento de cada linguagem das artes é de extrema importância, exigindo que o professor responsável pelas aulas esteja seguro de suas atribuições, no sentido de não reduzir as possibilidades de aprendizagem em artes na escola, como em qualquer outra área do conhecimento.

\footnotetext{
${ }^{5}$ Disponível http://www2.camara.leg.br/legin/fed/lei/2016/lei-13278-2-maio-2016-782978publicacaooriginal-150222-pl.html
}

SILVA, Genildo Gonçalves da; PONTOS, Francini Barros. Na pele: construções artísticas estabelecidas através da brega. Revista da FUNDARTE, Montenegro, p.456-482, ano 19, no 37, Janeiro/Março.

Disponível em: http://.seer.fundarte.rs.gov.br/index.php/RevistadaFundarte/index> 30 de março de 2019. 


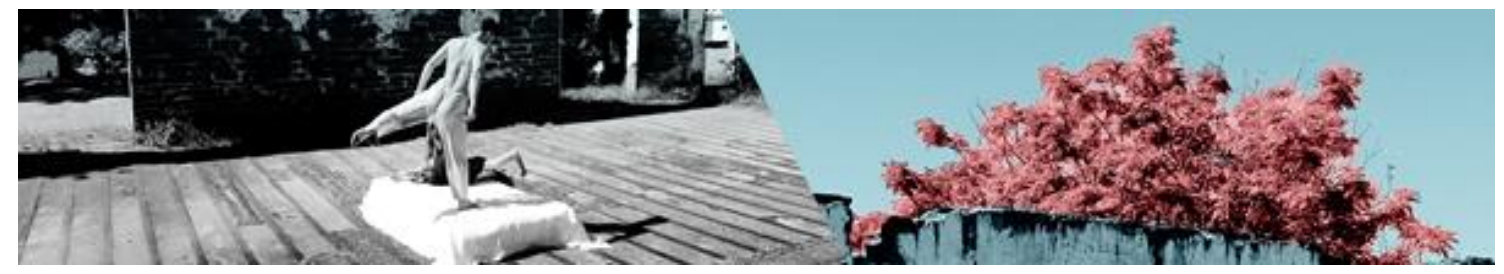

Sem dúvida, a docência em dança torna-se um desafio, principalmente quando se propõe a abordar uma cultura dita pela sociedade como marginalizada. A qualificação dos professores é de suma importância, pois eles têm a função de serem os mediadores entre o conhecimento e o aluno, provocando a ação dos últimos no processo de ensino aprendizagem. Martins (1998) ressalta sobre a importância da presença da mediação, por parte do professor: "para isso, é fundamental que o educador atue em sala de aula como o mediador dos conhecimentos dando o suporte necessário na aprendizagem.” (MARTINS, 1998, p.141).

O papel do professor, portanto, é de extrema responsabilidade, ao se propor ministrar as aulas de artes supondo que não deve oferecer um ensino pronto e acabado aos alunos, mas devendo produzir o saber juntamente com eles.

No decorrer das práticas em dança, foram surgindo várias reflexões e questionamentos: será que o está sendo ensinado nas aulas de Artes é realmente arte? Por isso faz-se necessário o reconhecimento do significado das artes e do valor de sua aplicação na sala de aula para a formação humana do aluno. As aulas de artes devem favorecer o acesso ao conhecimento das quatro linguagens que constituem a área de conhecimento, através de conteúdos significativos para os alunos, buscando um aprendizado que vai além das datas comemorativas ou da atuação deles em atividades descontextualizadas, desconexas. Martins (1998) discorre sobre como as aulas de artes são confundidas com outras atividades:

[...] ainda é comum as aulas de Artes serem confundidas com lazer, terapia, descanso das aulas "sérias", o momento para fazer a decoração da escola, as festas, comemorar determinada data cívica, preencher desenhos mimeografados, fazer o presente do Dia dos Pais, pintar o coelho da Páscoa e a árvore de Natal. (MARTINS, 1998, p.12)

Neste estudo sobre o lugar ocupado pela disciplina de artes no espaço escolar, recorremos novamente à "abordagem triangular", de Barbosa no que diz respeito ao desenvolvimento da capacidade criativa e crítica do aluno, no fazer

SILVA, Genildo Gonçalves da; PONTOS, Francini Barros. Na pele: construções artísticas estabelecidas através da brega. Revista da FUNDARTE, Montenegro, p.456-482, ano 19, no 37, Janeiro/Março.

Disponível em: http://.seer.fundarte.rs.gov.br/index.php/RevistadaFundarte/index> 30 de março de 2019. 


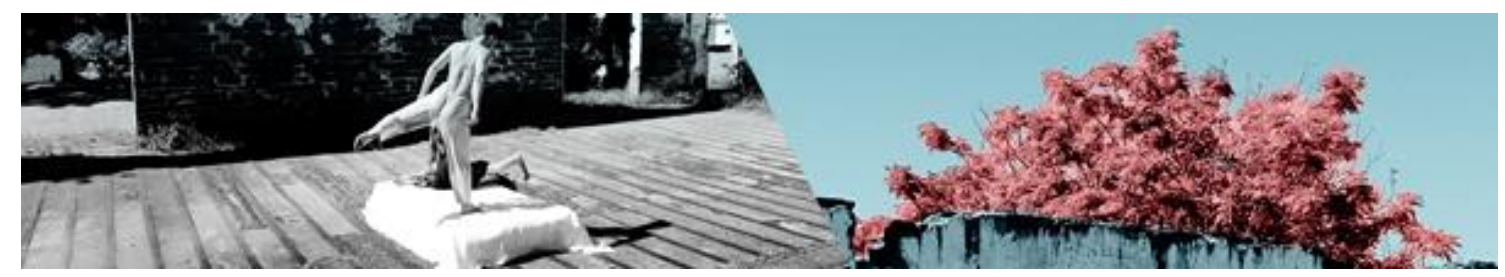

artístico e na sua reflexão sobre o processo de produção de arte, definitivamente comprometidos pela utilização simplória das linguagens das artes nos eventos comemorativos da escola.

No decorrer das aulas de artes, foi possível perceber como a atuação da docente se distancia da proposta sistematizada por Barbosa (2007), que defende que o ensino das artes deve ser garantido no currículo escolar, principalmente no que diz respeito à ação do professor. Percebe-se que a obrigatoriedade do ensino da área de conhecimento não é suficiente para que realmente as artes existam na escola. Dessa forma, cabe ao professor buscar meios para que o ensino dessa disciplina aconteça de forma efetiva na sala de aula, cumprindo os objetivos de formar os alunos para que sejam capazes de criar, apreciar e contextualizar produções artísticas.

O trabalho realizado propiciou uma reflexão sobre a necessidade premente de se repensar a ocupação da disciplina de artes no espaço escolar, uma vez que os professores que mediam a disciplina têm formação em outras áreas de conhecimento. A escola deve reconhecer a disciplina de artes como uma área de conhecimento, composta por quatro campos específicos, como sendo tão importante quanto às outras disciplinas que compõe a grade curricular. Antes de tudo, é necessário que as aulas de artes sejam ministradas por um docente especializado na linguagem em questão, de forma a valorizar e imprimir o compromisso com o ensino, contribuindo de maneira eficaz para o desenvolvimento das capacidades criativas do aluno.

\section{O ENSINO DA DANÇA NA ESCOLA NA CONTEMPORANEIDADE}

A inserção do ensino da dança no espaço escolar configura-se como um processo complexo uma vez que, historicamente, a dança coexiste nas disciplinas de artes e de educação física. Assim, para compreender a dança em suas interrelações com a sociedade, é necessário manter um olhar atento para a formação humana e a educação, considerando a importância educacional da dança, como um

SILVA, Genildo Gonçalves da; PONTOS, Francini Barros. Na pele: construções artísticas estabelecidas através da brega. Revista da FUNDARTE, Montenegro, p.456-482, ano 19, ㄲo 37, Janeiro/Março.

Disponível em: http://.seer.fundarte.rs.gov.br/index.php/RevistadaFundarte/index> 30 de março de 2019. 


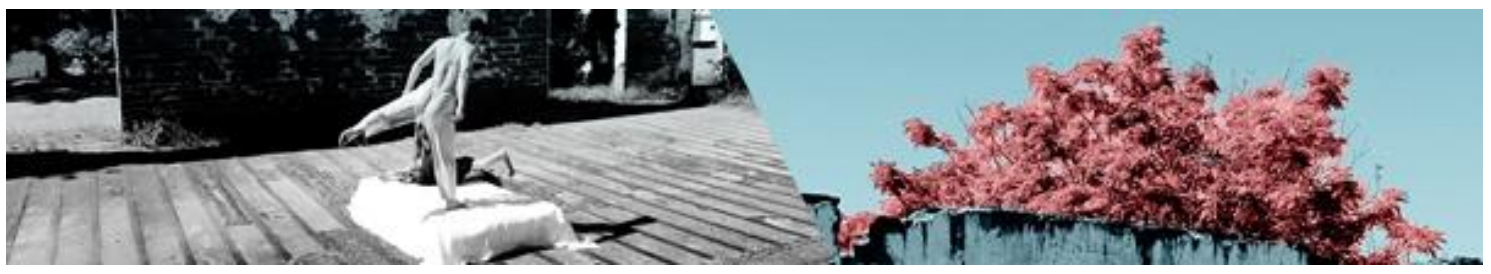

objeto de conhecimento a ser apropriado, de forma que ela seja democratizada e ressignificada no contexto escolar.

Jéssica Pistori (2010, p.14) afirma que "a dança como instrumento educativo ainda não tem sido compreendida em suas potencialidades para a formação educacional, cultural e histórica de crianças e jovens dentro do espaço escolar." (SILVA, J. P, 2010, p.14). Tampouco a dança, ao ser inserida como conteúdo escolar, pretende formar artistas e bailarinos, antes disso, ela é pensada de forma a oferecer uma relação efetiva e intimista com a possibilidade de aprender e expressar-se criativamente através do movimento. Nessa perspectiva, o papel da dança na educação é o de contribuir com o processo de ensino-aprendizagem, de forma a auxiliar o aluno na construção do seu conhecimento.

Não é de se admirar, portanto, que uma arte como a da dança, que trabalha direta e primordialmente com o corpo, tenha sido durante séculos "presa nos porões e escondidas nas senzalas": foi banida do convívio de outras disciplinas na escola, ou, então, atrelada ao tronco e chicoteada, até que alguma alma boa pudesse convencer "o feitor" de sua "inocência". (MARQUES, 2003, p.18).

A autora questiona o fato da dança ser vista superficialmente dentro dos espaços escolares, o que tem por consequência a permanência da ideia de que a dança na escola é boa somente "para relaxar", para "soltar emoções", "expressar-se espontaneamente" (MARQUES, 2007, p. 23). O espaço destinado à dança na escola tem sido atrelado às datas comemorativas, ocasiões festivas, shows de talentos, para os quais é oferecido às crianças um tempo do turno escolar (geralmente na Educação Física) para o ensaio de uma determinada coreografia, comumente representativa de determinada cultura. A dança no espaço escolar nos dias atuais vem tentando se sobressair da exclusão de sua potencialidade enquanto área de conhecimento. Uma vez que as escolas ainda vêm passando pelo processo de adaptação do ensino da dança, mesmo ela sendo reconhecida nos Parâmetros Curriculares Nacionais (PCNs) de 1997, como linguagem das Artes e determinada sua importância como forma de conhecimento a ser trabalhado na escola. A dança está inserida no bloco das atividades rítmicas e expressivas como uma manifestação

SILVA, Genildo Gonçalves da; PONTOS, Francini Barros. Na pele: construções artísticas estabelecidas através da brega. Revista da FUNDARTE, Montenegro, p.456-482, ano 19, nํ37, Janeiro/Março.

Disponível em: http://.seer.fundarte.rs.gov.br/index.php/RevistadaFundarte/index> 30 de março de 2019. 


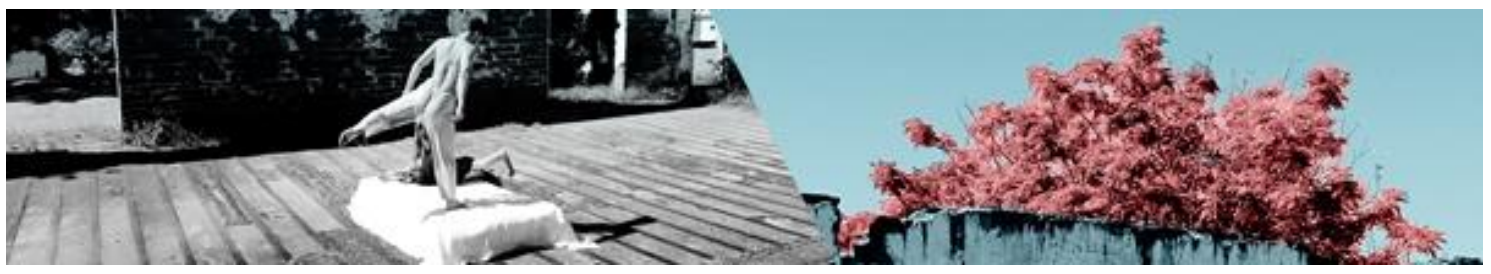

da cultura corporal. Portanto, para repensar 0 ensino de dança na contemporaneidade também se faz necessário pensar na formação dos professores que atuam na linguagem. Jéssica Pistori (2010, p.25) afirma:

\begin{abstract}
Vale ressaltar, no entanto, que para muitos pedagogos, professores de Educação Física, artes e outras áreas do conhecimento, se tornar apto para o ensino de dança é uma questão que vai além da oferta de parâmetros, pois o trabalho de professores 'mais ou menos' preparados para trabalhar com a dança implicará sempre numa formação 'mais ou menos' artística e/ou cultural para seus alunos. O que entendemos é que, os PCNs e as Diretrizes Curriculares Estaduais, ao incluírem o ensino de dança como componente curricular a ser trabalhado nas áreas de conhecimento de artes e educação física, realizam um movimento de avanço para mudanças em relação ao senso comum presente na cultura escolar sobre a dança como elemento educativo, mas insuficiente perante outras questões como a própria formação dos professores. (SILVA, J. P, 2010, p.25).
\end{abstract}

Presume-se que a não inserção do ensino da dança nos espaços escolares está ligada não só a escaches de profissionais, mas, pela falta de comprometimento do sistema, que por sua vez exclui as artes enquanto área de conhecimento, ou, quando inclui, não reconhece sua importância na formação do cidadão. A dança no ensino escolar é um tema pouco discutido pela má formação dos profissionais atuantes, no que tange o estabelecimento de um diálogo consistente com as diversas manifestações culturais existentes, por sua ausência efetiva no currículo das escolas, pelo caráter modelar de seu ensino tradicional. Ela começa, no entanto, a conquistar espaço em pesquisas acadêmicas, o que exemplifico através das autoras Isabel Marques, Márcia Strazzacappa e Ida Freire, as quais buscam problematizar como se desdobra a prática em dança na educação formal.

Em relação ao conteúdo ensinado nas escolas, no que diz respeito ao ensino modelar das danças tradicionais, ele produz corpos submissos ao propor a reprodução de movimentos estabelecidos sem diálogo, sem respeito às subjetividades ou mesmo sem a devida contextualização. Desse modo, vai se deixando de lado a autonomia dos alunos no processo de criação, desconsiderando que a participação dos mesmos é essencial em toda construção e o resultado de tal prática é a produção de corpos robotizados e estereotipados. Deste modo, (FERREIRA, 2001, p.15) afirma que:

SILVA, Genildo Gonçalves da; PONTOS, Francini Barros. Na pele: construções artísticas estabelecidas através da brega. Revista da FUNDARTE, Montenegro, p.456-482, ano 19, no 37, Janeiro/Março.

Disponível em: http://.seer.fundarte.rs.gov.br/index.php/RevistadaFundarte/index> 30 de março de 2019. 


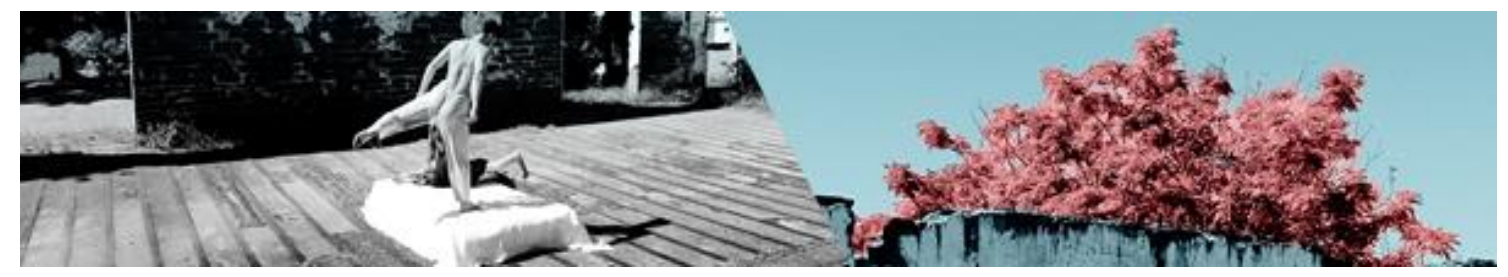

[...] o motivo mais importante para incluirmos as artes no currículo da educação básica é que elas são parte do patrimônio cultural da humanidade, e uma das principais funções da educação é preservar esse patrimônio dá-lo a conhecer. As artes são produções culturais que precisam ser conhecidas e compreendidas pelos alunos, já que é nas culturas que nos constituímos como sujeitos humanos. (FERREIRA, 2001, p.15).

O ensino da Dança pode ser estratégico no sentido de gerar experiências estéticas que possam transformar valores, conceitos e habilidades físicas, sendo significativo no processo de formação de identidades individuais e de diferentes grupos sociais. Nesse sentido, é importante pensar em quais estratégias devemos adotar nas nossas práticas pedagógicas. $\mathrm{O}$ que tem se mostrado é que a dança permanece como um grande desafio ao ser, ainda, pouco compreendida em suas potencialidades educativas. Assim, perante este contexto, podemos compreender que a dança, quando bem empregada, tem se tornado uma linguagem alternativa nas práticas pedagógicas, por orientar os movimentos corporais de cada aluno de forma a explorar suas capacidades de criação. Isabel Marques (2003, p. 142) afirma:

A dissociação entre o artístico e o educativo implícita na terminologia utilizada por professores de dança só vem reforçando a concepção de ensino de dança como meio, recurso, instrumento. Ou seja, ao enfatizarmos que a dança na escola é "diferente" (e por isso ela é "criativa", "educativa", "expressiva"), pois não estamos interessados em formar "artistas", acabamos também negando a presença da dança na escola como área de conhecimento em si, ou seja, como arte. (MARQUES, 2003, p. 142).

Para Marques o ensino da dança está associado aos princípios de diversificação das ações corporais, fundamentos como: movimento, espaço, forma, dinâmica e tempo são princípios que podem nortear o trabalho da educação da linguagem corporal. Para Laban Rudolf Von Laban, pioneiro da dança educativa moderna, a técnica de dança se desdobra a partir de movimentações livres, sem regras específicas. Como arte, a dança supõe e expressa uma bagagem de conhecimentos, tradição, evolução histórica, princípios que podem ser constatados nas imagens criadas, no método, nas relações entre formas e estilos de movimento.

SILVA, Genildo Gonçalves da; PONTOS, Francini Barros. Na pele: construções artísticas estabelecidas através da brega. Revista da FUNDARTE, Montenegro, p.456-482, ano 19, no 37, Janeiro/Março.

Disponível em: http://.seer.fundarte.rs.gov.br/index.php/RevistadaFundarte/index> 30 de março de 2019. 


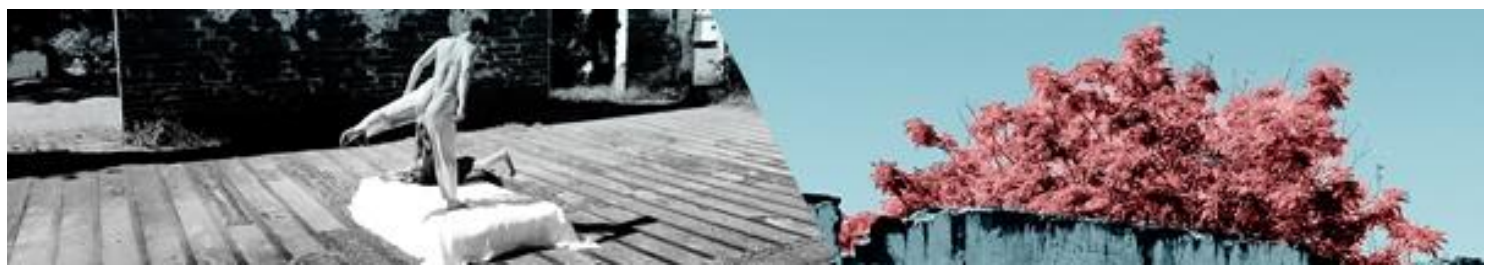

Desse modo, a escola deve desenvolver as capacidades físicas, afetivas, cognitivas e estéticas dos alunos, para uma formação ampla, humanista e ética. A capacidade física engloba o uso do corpo na expressão de emoções, nos jogos, no deslocamento com segurança. A escola deve desenvolver a corporeidade dos alunos, em todas as áreas, não apenas em educação física e artes. Através da dança, podemos desenvolver noções de execução simultânea e sucessiva dos movimentos, trabalhar em diferentes bases de sustentação, perceber e aplicar distintas trajetórias espaciais para os movimentos nos planos, nos níveis, estabelecer linhas para os segmentos corporais e desenhos das formas.

Por meio do ensino da dança é possível ainda aplicar variações da intensidade da força nos gestos, perceber a passagem da força aplicada de uma parte para outra, do peso de cada parte e do corpo como um todo, da velocidade que as partes se movem, e o ritmo que elas estabelecem e da relação das partes com os movimentos do corpo como um todo através das locomoções, voltas, saltos, quedas e elevações. Esses processos permitem que os alunos experimentem em seus corpos novas possibilidades de criação, explorando seus sentimentos e ideias de mundo. Convidando os alunos a viagens imaginativas, a comunicar e expressar pensamentos e emoções, retratando seu desenvolvimento pessoal e cultural.

Quando criamos e nos expressamos por meio da dança, quando executamos e interpretamos seus ritmos e formas, preocupamo-nos exclusivamente com o manejo de seu material, que é o próprio movimento. Por meio dos movimentos de nosso corpo aprendemos a relacionar nosso ser último com o mundo exterior. Recebemos de fora impressões que nos fazem reagir e, assim mesmo, projetamos para fora nossos impulsos internos espontâneos, com o que expressamos a presença da energia vital. (LABAN, 1990, p. I08).

A dança no espaço escolar nos dias de hoje se caracteriza pela mecanização dos movimentos, que, por sua vez, rouba o direito à criação dos alunos. A "robotização" 6 se desdobra por movimentos padronizados pela imitação, prescritos, inventados e propagados pelos professores, arraigados nos valores culturais e

\footnotetext{
6 Utilizo o termo robotização numa alusão à produção de movimentos e ações através de um processo simplificado de cópia dos mesmos, exclusivamente, com vias à constante e massificada reprodução que exclui os processos criativos e singulares de criação de movimentos.
}

SILVA, Genildo Gonçalves da; PONTOS, Francini Barros. Na pele: construções artísticas estabelecidas através da brega. Revista da FUNDARTE, Montenegro, p.456-482, ano 19, no 37, Janeiro/Março.

Disponível em: http://.seer.fundarte.rs.gov.br/index.php/RevistadaFundarte/index> 30 de março de 2019. 


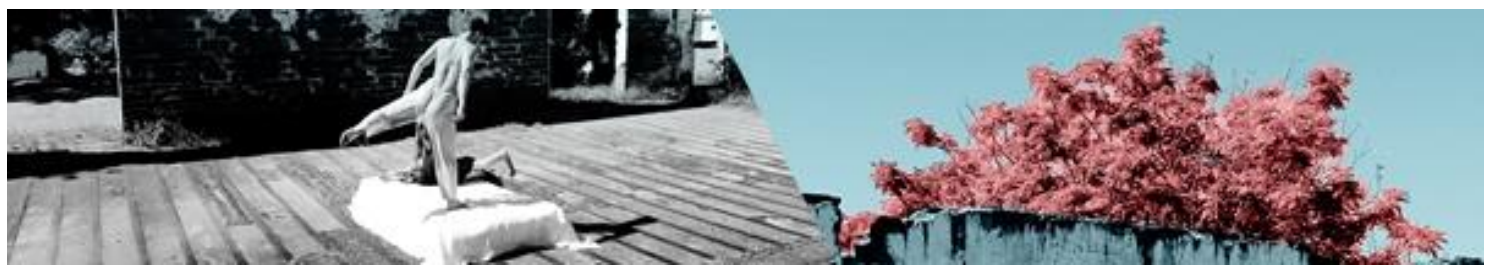

sociais. O aprendizado da dança deve integrar o conhecimento intelectual e a criatividade do aluno. A imitação como fim, e não como um dos recursos possíveis à aprendizagem, inibe a construção da teatralidade e da dança singular de cada um que, por sua vez, nos proporcionariam modos de olhar, de tocar, de nos manifestarmos, de nos erguermos. Márcia Strazzacappa (2003, p. 74) indaga:

\begin{abstract}
A dança sempre esteve numa situação inferior à das demais manifestações artísticas. No universo político, ela fica à mercê das secretarias de artes cênicas do Ministério da Cultura, onde se costuma ler "Teatro". Embora a dança seja reconhecida pelo Ministério da Educação como um curso superior com diretrizes próprias desde a década de 1970, sua fiscalização é feita por profissionais formados em sua maioria na área de teatro e/ou educação. $\mathrm{Na}$ educação básica, isto é, nas escolas de ensino regular, ela costuma ser vista como conteúdo da Educação Física, fato claramente indicado nos Parâmetros Curriculares Nacionais (PCNs) da área dessa disciplina. Embora as Diretrizes situem a dança como uma das linguagens do ensino de arte nas escolas, ela é apresentada ora como complemento das aulas de música, sobretudo quando se estudam as manifestações populares, ora como conteúdo da Educação Física, quando aparece nas comemorações cívicas do calendário escolar. Quando a dança finalmente é oferecida no ambiente escolar como uma atividade em si, aparece como disciplina optativa de caráter extracurricular. (STRAZZACAPPA, HERNANDEZ, M. M, 2003, p. 74).
\end{abstract}

A estrutura das aulas tradicionais nas escolas, que mantém os alunos inertes em suas carteiras por horas, é desafiada pela dança ao contestar a "repressão da movimentação", que reverbera em corpos rígidos que buscam se integrar por meio da dança. Ela se torna um instrumento ao oferecer possibilidades de fuga das estruturas que bloqueiam ou estreitam as formas de pensar do/no corpo. Logo, fazse necessária uma reflexão: que tipo de corpo se dispõe nas carteiras, pesadas e dispostas umas atrás das outras? A sensação de aprisionamento é constante ao entrar nas salas de aula na atualidade, bem como o layout das salas é um dos fatores que influenciam o ensino/aprendizagem. Dessa forma, promover um ambiente escolar sem barreiras permite uma integração maior entre professores e alunos. Essa proposta se resume na busca de uma prática pedagógica mais coerente com a realidade escolar, buscando cada vez mais quebrar, fragmentar e expulsar todas as barreiras que possam dificultar o entendimento dos alunos. Logo, faz-se necessária a conscientização de que a dança preparará os alunos,

SILVA, Genildo Gonçalves da; PONTOS, Francini Barros. Na pele: construções artísticas estabelecidas através da brega. Revista da FUNDARTE, Montenegro, p.456-482, ano 19, no 37, Janeiro/Março.

Disponível em: http://.seer.fundarte.rs.gov.br/index.php/RevistadaFundarte/index> 30 de março de 2019. 


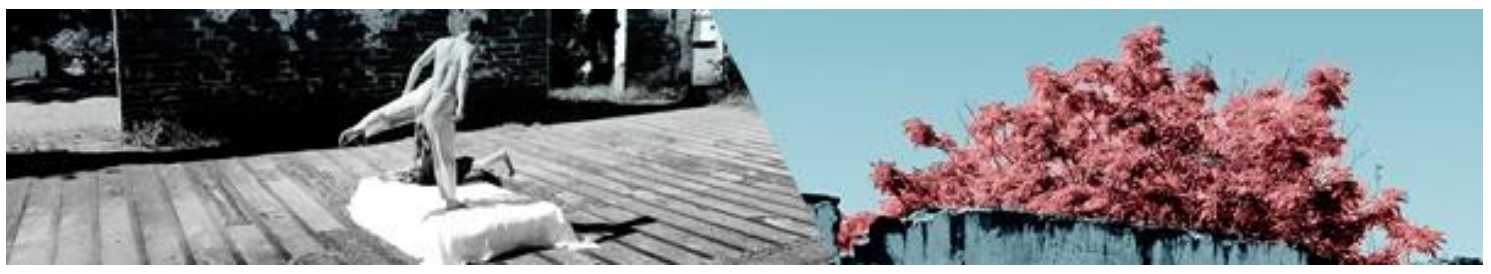

entendendo-os de forma integral, a fim de que se exercitem de acordo com suas necessidades, estimulando, através dos movimentos espontâneos e da precisão do gesto, o processo de ensino/aprendizagem. Segundo Vanessa Gertrud Franciscchi (2011, p.36):

Neste sentido, os processos pedagógicos da dança na escola voltam-se para uma reformulação da compreensão de corpo e de movimento humano, buscam considerar as possibilidades de movimento de cada sujeito e, a partir disso, descobrir novas formas de se movimentar e de se expressar. Portanto, educar através do movimento é garantir aos alunos/as o direito de todos/as aprenderem e compartilharem brincadeiras, danças, esportes, entre outras práticas corporais, cada um/a no seu tempo e ritmo de aprendizado. (FRANCISCHI, 2011, p.36).

Nota-se a diferença entre duas tendências relacionadas ao uso do corpo em sala de aula. Para muitos professores, o corpo parece ser empecilho no momento da aprendizagem. Dizem eles que aluno bom é o que está sempre quietinho em seu lugar, que só participa, só se movimenta, quando é chamado à lousa, na fila, no recreio, na saída. Aluno "disciplinado", "obediente", "bonzinho" mantém-se quieto e imóvel. São essas estruturas de corpos que precisam ser colocadas de lado, dando um novo olhar a esse corpo que, ao longo do tempo, vem sendo estereotipado e recriminado. Dessa forma, faz-se necessário elaborar estratégias que utilizem os corpos dos alunos, a fim de que eles possam participar, interferir, construir e não somente ficar quietos, ouvindo, o que os tornará mais motivados e envolvidos com a escola. Os professores tomam o lugar ativo na construção de diálogos entre o corpo que dança e o corpo na dança, tornando-se fonte de conhecimento sistematizado e transformador. A escola, em geral, configura-se como um ambiente sério e monótono; os professores, sisudos e corporalmente rígidos. É nítido o medo presente no ambiente escolar ao se deparar com inovações, de técnicas que tragam o prazer e o interesse aos alunos. Assim, justificamos, através do ensino da dança, - desenvolvimento da capacidade de expressão e comunicação para o autoconhecimento, o domínio corporal, a adaptação das bases de uma expressão livre e consciente.

SILVA, Genildo Gonçalves da; PONTOS, Francini Barros. Na pele: construções artísticas estabelecidas através da brega. Revista da FUNDARTE, Montenegro, p.456-482, ano 19, no 37, Janeiro/Março.

Disponível em: http://.seer.fundarte.rs.gov.br/index.php/RevistadaFundarte/index> 30 de março de 2019. 


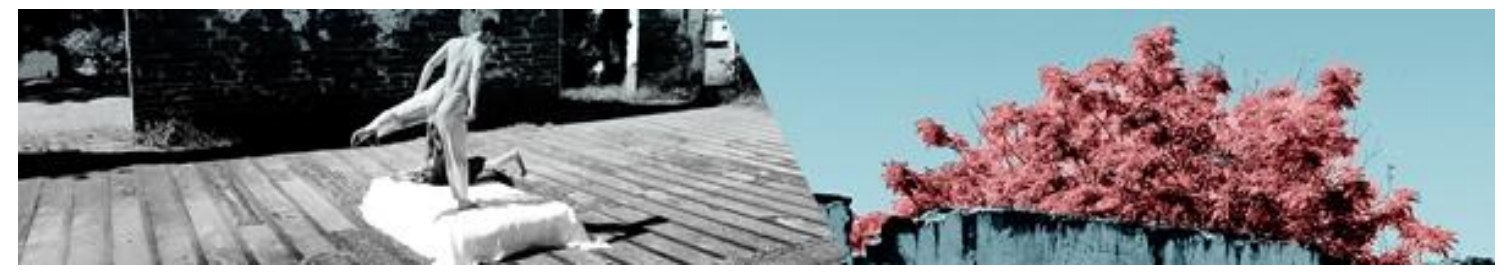

\section{INTERFACES METODOLÓGICAS E SUAS POSSIBILIDADES}

O estudo que aqui se apresenta, configura-se como uma pesquisa descritiva com desdobramento a partir da pesquisa-ação, visando obter 0 máximo de informações e permitir um conhecimento amplo e detalhado de práticas corporais a partir do brega e suas construções metodológicas, buscando melhorias nas condições de vida dos alunos. Para tanto, foram adotados como recursos os métodos de improvisação, como norteadores para as práticas corporais que coexistem entre si.

Um dos pioneiros da pesquisa-ação foi o psicólogo alemão Kurt Lewin (18901947). Na década de 1960, na área da Sociologia, ganhou terreno a ideia de que o cientista social deveria sair de seu isolamento, assumindo as consequências dos resultados de suas pesquisas e colocá-los em prática, para interferir no curso dos acontecimentos.

A pesquisa-ação é um instrumento valioso, ao quais os professores podem recorrer com o intuito de melhorarem o processo de ensino-aprendizagem, pelo menos no ambiente em que atuam. O benefício da pesquisa-ação está no fornecimento de subsídios para o ensino: ela apresenta ao professor subsídios razoáveis para a tomada de decisões, embora, muitas vezes, de caráter provisório. (ENGEL, G. I. Pesquisa-ação Educar, Curitiba, n. 16, p. 2000).

Nesse contexto, foram realizadas intervenções em uma escola estadual da cidade do Recife, onde trabalhamos questões relativas à inserção do brega enquanto recurso didático-pedagógico e como ferramenta metodológica para a condução das aulas. Buscamos estabelecer interdisciplinaridade com as mais diversas áreas do conhecimento, presentes no cotidiano dos estudantes no espaço escolar. Estas intervenções tiveram uma duração de quatro meses, a fim de estabelecer um maior vínculo de confiabilidade da amostra. Além disso, foram abordadas questões relacionadas ao sexo e as sexualidades, uma vez que esta é uma temática amplamente discutida no brega. Nesse sentido, pretendeu-se também, a partir dos recursos metodológicos, abordar questões relativas a estupro, submissão da mulher, drogas e problemas relacionados ao campo sexual na fase da juventude e que nem sempre são trabalhadas pelos familiares e tampouco pelos professores.

SILVA, Genildo Gonçalves da; PONTOS, Francini Barros. Na pele: construções artísticas estabelecidas através da brega. Revista da FUNDARTE, Montenegro, p.456-482, ano 19, no 37, Janeiro/Março.

Disponível em: http://.seer.fundarte.rs.gov.br/index.php/RevistadaFundarte/index> 30 de março de 2019. 


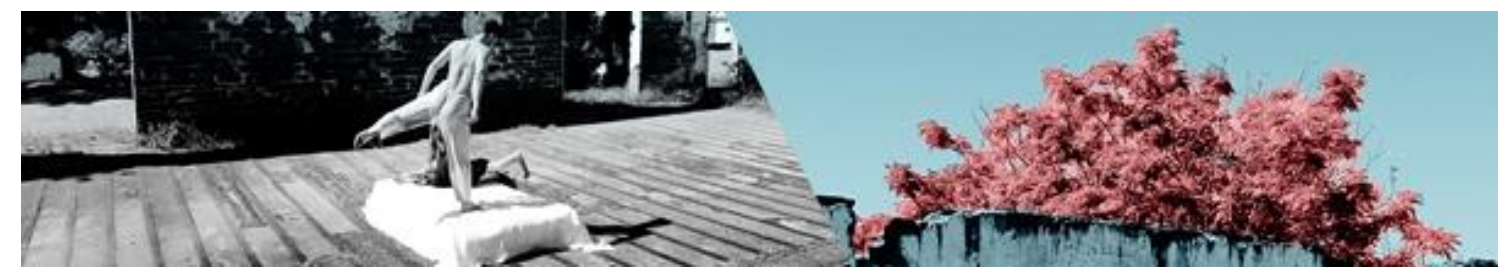

Para a coleta de dados foi utilizado o diário de campo, e a observação participante. A fase denominada como campo de observação e colaboradores do estudo teve como foco compreender junto aos estudantes, professores e professoras como o brega se manifesta no contexto escolar, bem como, suas necessidades de sistematização enquanto prática pedagógica presente na escola.

\section{CONCLUSÃO}

Diante dos dados já analisados e discutidos anteriormente concluímos que a presença da dança nas disciplinas de artes não está legitimada na escola pesquisada, entretanto, ela se encontra presente de forma espontânea entre os/as estudantes em outros tempos e espaços que configuram o ambiente da escola. É possível reconhecer, através das observações, que a dança está presente não só no cotidiano escolar, mas também no cotidiano vivenciado pelos alunos fora da escola. Tal fato permite estabelecer importantes e significativas relações entre algumas categorias como corpo, gênero e sexualidade, categorias essas que foram discutidas e problematizadas na escola. Com isso percebemos a necessidade de ampliar as possibilidades de interlocução entre o contexto e as dinâmicas sociais em que a dança se faz presente e o contexto escolar, entendendo a escola como um grande palco do mundo vivido e expressado pelos corpos dançantes.

A presente pesquisa buscou identificar como é a inserção do brega enquanto conteúdo e desenvolvimento metodológico nas práticas em dança na ocupação da disciplina de artes no espaço escolar, principalmente no sentido de verificar se é uma prática significativa para os alunos, não somente a partir das aulas de dança, mas da análise dos dados coletados no diário de campo, que contém a observação dos participantes. A fase denominada "campo de observação e colaboradores do estudo" teve como foco: compreender junto aos estudantes, professores e professoras como o brega se manifesta no contexto escolar e quais suas necessidades de sistematização enquanto prática pedagógica presente na escola. Na EREM Diário de Pernambuco, na cidade de Recife - PE, foi possível constatar

SILVA, Genildo Gonçalves da; PONTOS, Francini Barros. Na pele: construções artísticas estabelecidas através da brega. Revista da FUNDARTE, Montenegro, p.456-482, ano 19, ㄲo 37, Janeiro/Março.

Disponível em: http://.seer.fundarte.rs.gov.br/index.php/RevistadaFundarte/index> 30 de março de 2019. 


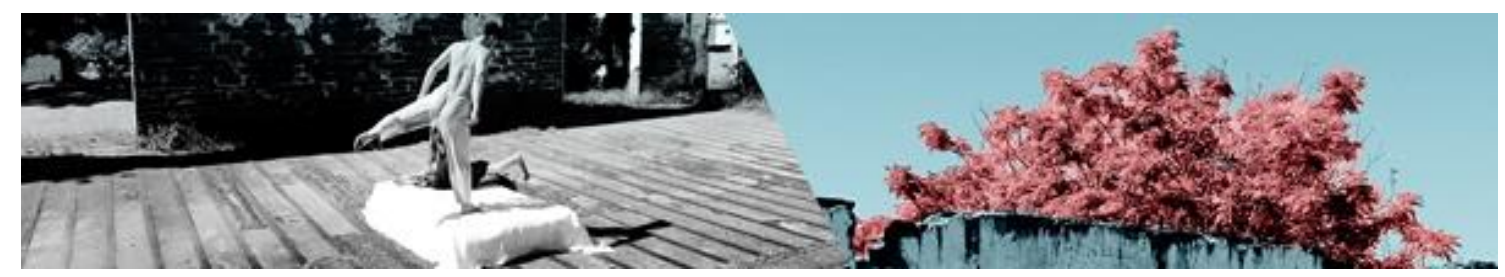

que o ensino da arte/dança vem sendo trabalhado de forma a não efetivar a valorização desta disciplina, com práticas desvinculadas da realidade dos alunos. A situação de não aprofundamento dos conhecimentos da área das artes, por meio da implementação de atividades de ensino descontextualizadas, está atribuída a diversos aspectos, principalmente à falta de formação continuada, que deveria ser promovida à professora para que esta desenvolvesse um trabalho prático em sala de aula, em consonância com o que é requerido nos Parâmetros Curriculares Nacionais para o ensino das artes na escola básica.

Em consonância com o pensamento de Barbosa (2007), a obrigatoriedade do ensino das artes não é o bastante para garantir existência desta disciplina no currículo. É necessário contar com as ações do professor para que o ensino tenha maior legitimidade no contexto escolar. Em outras palavras, é muito importante que o professor de artes receba a devida formação para atuar de modo que os alunos tenham um contato efetivo com os conhecimentos específicos da área de conhecimento na escola e aprendam a identificar os diversos fenômenos artísticos em seu cotidiano. Apesar de os professores de artes da rede estadual de Pernambuco passar, a cada semestre, por capacitações referentes ao ensino, em caráter obrigatório para todos os professores que ministram aulas de artes, observamos não serem elas efetivas na preparação dos professores.

Durante a realização da pesquisa foi possível observar que os alunos, apesar de afirmarem gostar da disciplina, não percebem sua importância por meio do ensino que lhes é ministrado. Desta maneira, percebeu-se que a contextualização do ensino de artes é essencial para que o aluno, ao verificar a presença de um dado conteúdo em seu cotidiano, aprenda a valorizar a disciplina de Arte no contexto escolar.

Para trabalhar com a disciplina de artes é necessário ter conhecimento e planejamento por parte do professor, ter objetivos claros, assim como promover o ensino de conteúdos, por meio de metodologias que favoreçam a identificação dos referenciais do aluno. Esses aspectos foram observados durante as aulas práticas.

SILVA, Genildo Gonçalves da; PONTOS, Francini Barros. Na pele: construções artísticas estabelecidas através da brega. Revista da FUNDARTE, Montenegro, p.456-482, ano 19, ㄲo 37, Janeiro/Março.

Disponível em: http://.seer.fundarte.rs.gov.br/index.php/RevistadaFundarte/index> 30 de março de 2019. 


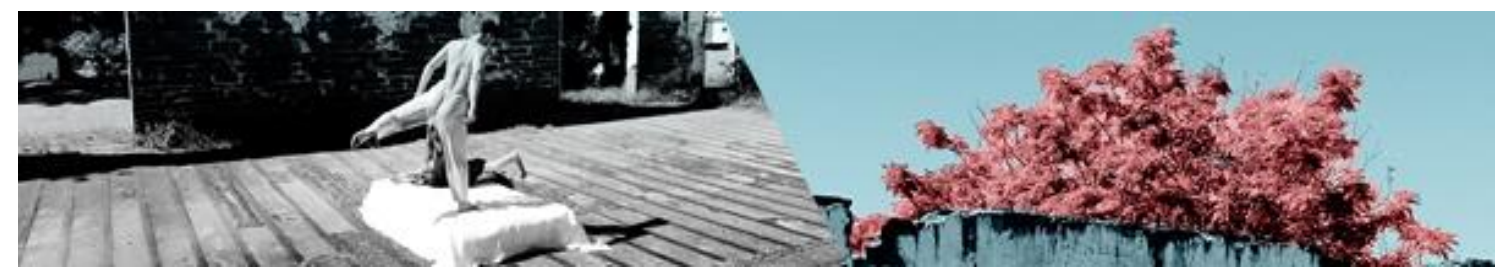

Para que o ensino das artes possa existir no currículo, sendo ele um ensino promissor com práticas significativas, além da obrigatoriedade, é preciso que o sistema educacional tenha ações concretas em relação à formação continuada dos professores de artes. Assim, por meio desta pesquisa, foi possível verificar ainda que a disciplina no ambiente escolar necessita de mudanças de modo a adquirir seu real valor perante as demais disciplinas. Tais mudanças envolvem a formação do professor, a utilização de materiais e espaços da escola e a exploração dos diversos tipos de demonstrações artísticas dos alunos que favoreçam sua percepção de como a arte está permeada em seu dia a dia.

\section{Referências:}

ALMEIDA, Renato Souza de. Cultura de periferia em movimento. Artigo da Revista Sesc. 2014. Disponível em:

< https://www.sescsp.org.br/online/artigo/8629_CULTURA+E+PERIFERIA >. Acesso em:26/09/2018.

ALVES, Pedro. Cosmopolitismo Brega - A Estética do Videoclipe na Cena Musical Brega do Recife. - Recife-PE: 2017

ANDRADE, Oswald de. O manifesto antropófago. In: TELES, Gilberto Mendonça. Vanguarda europeia e modernismo brasileiro: apresentação e crítica dos principais manifestos vanguardistas. 3aㅡ ed. Petrópolis: Vozes; Brasília: INL, 1976.

ESTEVES, Eduardo. De Labaredas a Troinha: o triunfo do Brega em Pernambuco. Reportagem do jornal Leia já. 2017. Disponível em <http://www.leiaja.com/cultura/2017/06/26/de-labaredas-troinha-o-triunfo-do-bregaem-pernambuco/>. Acesso em: 20/09/2018.

FREIRE, João Batista. Educação de corpo inteiro: teoria e prática da educação física. 3aㅡ edição. São Paulo: Scipione, 1992

FREITAS, Ricardo O. de; et al. Caderno de formação de educadores: projeto dinamização da juventude. Rio de Janeiro: Fundação Roberto Marinho/Secretaria Geral da Presidência da República/Secretaria Nacional da Juventude, 2006.

LABAN, R. Domínio do movimento. São Paulo: Summus, 1978.

LOURO, Guacira Lopes. Gênero, sexualidade e educação: uma perspectiva pós-

SILVA, Genildo Gonçalves da; PONTOS, Francini Barros. Na pele: construções artísticas estabelecidas através da brega. Revista da FUNDARTE, Montenegro, p.456-482, ano 19, ํㅡ 37, Janeiro/Março.

Disponível em: http://.seer.fundarte.rs.gov.br/index.php/RevistadaFundarte/index> 30 de março de 2019. 


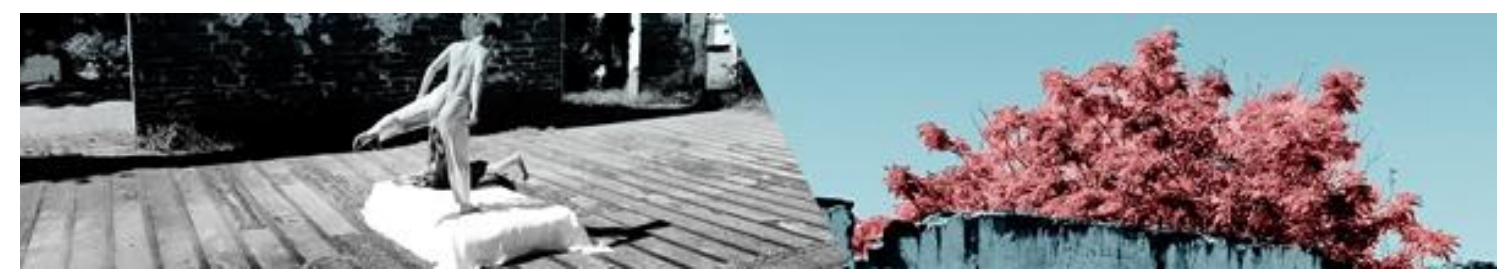

estruturalista. Petrópolis, Rio de Janeiro: Vozes, 1997.

MARTINS, M. C.; PICOSQUE, G. GUERRA, M.T.T. Didática do ensino da Arte. São Paulo: Editora FTD, 1998.

NUNES, Sandra Meyer, O criador-intérprete na dança contemporânea, Revista Nupearte, setembro- 2002.

PORTO, Eline e MOREIRA, Wagner. Diversidade Humana: a corporeidade em movimento na dança. In: Dança e Diversidade Humana. Org. Tolocka e Verlengia. Campinas: Papirus, 2006.

RODRIGUES, N. ONGs: A SOCIEDADE CIVIL E O PAPEL DO ESTADO. In: XXIV Semana de Ciências Sociais, 2013, Londrina-. Tema: - Desafios Contemporâneos. Londrina: UEL -, 2013.

SCOTT, Joan. Gênero: uma categoria útil de análise histórica. Educação \& Realidade, Porto Alegre, v. 16, n. 2, p. 5-22, jul./dez. 1990. Gênero: uma categoria útil de análise histórica. Educação \& Realidade, Porto Alegre, v. 20, n. 2, p. 71-99, jul./dez. 1995.

SILVA, Andressa Hening, FOSSÁ, Maria Ivete Trevisan. Análise de Conteúdos: Exemplo de Aplicação da Técnica para Análise de Dados Qualitativos. In: IV Encontro de Ensino e Pesquisa em Administração e Contabilidade. Brasília, 2013.

SILVA, Fabiana Roncaglio da. A dança no processo ensino e aprendizagem de crianças da educação infantil: algumas considerações. 2012. Trabalho de conclusão de curso (Pós- graduação) - Curso em Educação Especial, Faculdade Assis Gurgacz. Paraná. 2012.

SILVA, J. N. Os desafios da gestão democrática. In: Educere, 2017. Curitiba. III Congresso Nacional da Educação. Curitiba: EDITOR, 2017.

SILVA, Josy Amélia; MARRA, Sumaia Barbosa Franco; PIAU, Eder Teixeira. O professor e cultura corporal da dança na escola: uma possibilidade para a educação física. 2008. Trabalho de conclusão de curso (Graduação) - Curso de Educação Física, UNICERP, Minas Gerais, 2008.

SOUSA, Eustáquia Salvadora de. Meninos à marcha! Meninas à sombra! A história do ensino da educação física em Belo Horizonte (1897 -1994). Campinas, Unicamp: 1994. 265f. Tese (Doutorado em Educação) Universidade Estadual de Campinas, Campinas, 1994.

STRAZZACAPPA HERNANDEZ, M. M. Dança na Educação: discutindo questões básicas e polêmicas. Pensar a Prática (UFG), Goiânia, v. 6, p. 73-85, 2003.

SILVA, Genildo Gonçalves da; PONTOS, Francini Barros. Na pele: construções artísticas estabelecidas através da brega. Revista da FUNDARTE, Montenegro, p.456-482, ano 19, no 37, Janeiro/Março.

Disponível em: http://.seer.fundarte.rs.gov.br/index.php/RevistadaFundarte/index> 30 de março de 2019. 